\title{
The Political Implications of Popular Support for Presidential Term Limits in Russia*
}

\author{
Paul Chaisty and Stephen Whitefield
}

Accepted by Post-Soviet Affairs on 26 April 2019

\begin{abstract}
With Vladimir Putin having commenced his second term, the issue of the constitutional limit of two successive terms for the president has again become politically salient in Russia. In this article, two specialists of Russian politics investigate public support in 2018 for term limits. They address three questions. Why does the issue of term limits matter? Who in Russia does it matter to? Is opposition to abolishing terms limits likely to be politically divisive? Their findings point in general to a shift in the level and character of support for term limits since 2012. Opposition to term limits has grown over time, and while in 2012 support for term limits was drawn from supporters of more authoritarian leadership, today it includes engaged democrats with negative views of the economic situation. Moreover, they find that supporters of term limits remain more likely to support political protest. Thus, any ending of term limits, they argue, is likely to mobilise a different coalition of political forces during the second term of Vladimir Putin's current presidency.
\end{abstract}

*The authors gratefully acknowledge financial support from The British Academy (grant number SG170167). 


\section{Introduction}

Limiting the number of terms a president may occupy in office is generally - though not universally - seen as having stabilising and positive effects on democracy. But, interest in term limits is not confined to democracies. Their importance also extends to authoritarian and hybrid regimes. In such political systems the absence of term limits is frequently a sign of anti-democratic consolidation. This is evident in the development of presidential systems across the post-Soviet world, where multiple instances of leaders removing term limits have occurred since the early 1990s (Baturo, 2014).

In Russian politics, the question of whether to remove term limits has appeared at regular intervals as presidents have entered their second and final terms in office. Hence, it is no surprise that this issue has become salient once again following Vladimir Putin's reelection in 2018. However, to date Russian presidents have desisted from changing the Constitution in this area. One possible explanation for this has been public support for termlimited presidents, and in this article we investigate whether this continues to be the case. While citizens in general are often assumed to lack clear constitutional preferences - though at moments of high political tension this may be less true (Chaisty and Whitefield, 2017) and in Russia elite domination of political institutions is clearly powerful, we argue that our focus on public attitudes is justified by the potential for mass political unrest that constitutional change might engender. The best example of this followed from analysis of the Bolotnaya protests in 2011-12 (Chaisty and Whitefield, 2013) in which citizens' views on the issue of the abolition of term limits was a strong predictor of their willingness to protest and to support protest.

To assess the state of public attitudes on presidential term limits at the start of the second term of Vladimir Putin's current presidency, this article first provides an historical 
overview of how and why term limits became part of the constitutional framework in postSoviet Russia and how and why the issue became politically salient at different points.

Second, it considers the main theoretical expectations about the consequences of term limits for a range of political outcomes and why we might therefore expect some citizens rather than others to support these outcomes. Third, it uses data from a nationally representative sample of Russians in 2018 to contrast support for term limits at the start of Putin's second term with public opinion in 2012 when the Bolotnaya protests were fresh in citizens' minds.

Our analysis will focus on three main empirical questions: Why do term limits matter in Russia? To whom do they matter - what kind of people with what sorts of views support or oppose them? Who might be mobilised politically, including potentially to protest, if term limits were abolished? The answers to these questions are important, we argue, for understanding the current character and potential political dynamics of the Russian political system. We find an important difference in the nature of support for term limits between 2012 and 2018. In the former period, and contrary to most theoretical expectations, those who supported term limits were more likely to be citizens willing to countenance authoritarian leadership. Putin's pivot to a nationalist agenda after his re-election, however, appears to have mitigated that relationship. Over time, opposition to term limits has grown. But in 2018 and in line with most theoretical expectations, were Putin to seek to rewrite the constitution to allow him to run for further terms, he would now be likely to face a coalition of politically engaged democrats with negative views of his economic stewardship. While Putin's popularity is not surprisingly a powerful driver of opposition to term limits, interestingly we note that the character of support for term limits is strikingly similar among Putin voters as it is in the rest of the population. Though the constituency of support for term limits has in some ways changed, those who favour them remain significantly more likely to engage in political protest. 
In Russia, much hinges on the security of the elite relationships that the continuation of Vladimir Putin's presidency provides. Therefore, the incentives for constitutional reform that would allow President Putin to remain in office are significant. However, a decision to do so is likely to face opposition, including among many of Putin's own supporters, for reasons that are strongly connected with the political effects that term limits are often held to provide: to stop tyranny, enhance citizens' sense of their political efficacy, and undermine clientelism. The temptations to keep Putin in power are clearly powerful ones in Russian politics, but with potentially important political effects in shaping and galvanising opposition.

\section{Term Limits and Russian Public Opinion}

In a political system where leadership authority centres on intricate networks of power that are highly personalised (Hale, 2015), rules designed to rotate leaders are potentially very threatening. Therefore, it is not surprising that the issue of term limits was an important one for those who designed Russia's political system in the early 1990s. Although it was not at the heart of the divisive constitutional conflict that followed the breakup of the Soviet Union, Russian rule makers were keenly aware of its significance (see Chaisty, forthcoming).

For those constitutional drafters who designed the 1993 Constitution for President Boris Yeltsin, the priority was for conditional term limits. Under their preferred institutional arrangement, presidents could serve multiple two-term presidencies. This gave Yeltsin and his supporters the flexibility that they desired to maintain their grip on power. Indeed, it was so important for the presidential side that they were even prepared to accept rules shortening presidential terms to just four years in return for a constitutional wording which stipulated that the two-term limit was active only for two terms served 'in a row'. 
Initially introduced as an amendment to the 1978 Soviet Constitution, ${ }^{1}$ Article $81-3$ of the 1993 Russian Constitution states that:

One and the same person cannot hold the office of the President of the Russian Federation for more than two terms in a row.

This conditional arrangement deliberately left open the possibility that presidents could serve more than two terms. As one perceptive participant at the 1993 Constitutional Convention remarked "This means that [a term-limited president] can sit out a third term and then be elected again for a fourth" (Konstitutsionnoye soveshchanie, 1995, p. 77). This interpretation of Article 81-3 was later realised by a ruling of the Russian Constitutional Court in 1998 (Zhukov, 1998), and while Boris Yeltsin did not have the political authority to take advantage of it, the re-election of Vladimir Putin for a second two-term stint in 2012 - after Dmitry Medvedev's one term in office - demonstrated its intended flexibility.

Nonetheless, the requirement that presidents leave office at the end of their second term still leaves a degree of uncertainty in Russian politics. Presidential office confers extraordinary powers and resources on the office holder, and departing presidents can never be entirely sure that their successors will agree to forgo this privilege and allow their return. This danger became even more likely when the Constitution was amended to extend the presidential term from 4 to 6 years in 2008. This change, which came into effect in 2012, has meant that any agreement similar to the one that enabled Putin to return to the Kremlin in 2012 would entail much greater risks.

The change of leadership at the top also has direct consequences for those whose power and influence derives from their personal ties to the president. The election of a new

\footnotetext{
${ }^{1}$ This constitutional amendment was introduced on 24 May 1991.
} 
leader will inevitability result in new patronage networks and the re-division of the spoils of office. ${ }^{2}$ Hence, it is not surprising that supporters of both Boris Yeltsin and Vladimir Putin advocated the abolition of term limits along with various schemes to mitigate their impact during their second terms in office. For instance, in 2007, as the end of Vladimir Putin's second term approached, an alliance of security (silovik) interests, pro-Kremlin parties and regional leaders backed a mass, nationwide campaign in support of a third term for Vladimir Putin (Dobrynina 2007; Coalson, 2007; Gordeev and V'iugin, 2007).

Yet, no Russian president has backed the removal of term limits to date. Indeed, Vladimir Putin has consistently spoken out against constitutional change in this area. During both his first second term (Kidenis, 2007), and within weeks of his re-election for a (second) second term in 2018, Putin repeated the same mantra about the need to uphold the Constitution (TASS, 2018). This is quite different from the behaviour of presidents in other post-Soviet political systems. In most post-Soviet cases, presidents have either ruled continuously beyond two terms (e.g. Belarus, Kazakhstan, Tajikistan, Turkmenistan, Uzbekistan) or have moved their constitutions in a parliamentary direction to extend their political careers and/or protect their interests once their time in office has expired (e.g. Armenia, Georgia, Kyrgyzstan and Ukraine).

One possible reason for the Russian exception has been the relatively low level of public support for the removal of term limits. In 2004, the government polling agency, the Russian Public Opinion Research Centre (VTsIOM), found that just one-third of respondents supported the idea that presidents should be able to serve for three or even four terms, with the largest number of those polled (around half) opposed to the idea (Golobachev, 2004). In

\footnotetext{
${ }^{2}$ This scenario has been played out in Kyrgyzstan in recent times, with the newly elected President Sooronbai Jeenbekov establishing his powerbase by ousting (often punitively) the supporters of his predecessor Almazbek Atambaev (RFE/RL, 2018).
} 
our own national survey of 1200 Russian citizens, which took place shortly after the presidential election of 2012 (see Appendix A), we again found similar responses. As can be seen in Table 1, half of the polled respondents agreed or strongly agreed with the statement that presidents should not serve more than two terms, with a slightly smaller percentage disagreeing with this idea than was the case in 2004.

- TABLE 1 -

These consistently high levels of popular support for term limits present presidential incumbents with uncertainty about how citizens would react to any constitutional change. The danger that the removal of term limits could even be politically destabilising was borne out in 2011, when Vladmir Putin's decision to return for a third term after Dmitry Medvedev's one-term presidency, was considered to be a violation of the spirit if not the letter of the Russian Constitution. According to our research (XXXXXX), citizens who supported the statement that presidents should not serve more than two terms in total were significantly more likely to support the protests that took place after the Duma elections in December 2011. In the immediate aftermath of these protests, Vladimir Putin even hinted at supporting changes to the Constitution that would prevent future presidents from serving more than two terms in total (Rodin, 2012).

Therefore, any discussion of term limits in Russia ought to assess the state of Russian public opinion. In this article, we consider the state of opinion on this issue at the start of the second term of Vladimir Putin's current presidency. With reference to polling data gathered directly after the presidential election of March 2018 (see Appendix A), we asked respondents to select one of four responses (from "entirely agree" to "entirely disagree") to the statement that "the same person cannot be president of Russia for more than two terms in total." The results are summarised in Table 2. They suggest that while support for term limits 
remains high, there has been a fall of around 9 percentage points in comparison with earlier surveys: from 52 per cent in 2012, to 43 per cent in 2018. More significantly, the percentage of respondents opposed to term limits has increased sharply: from 20 per cent in 2012, to 47 per cent in 2018. Although we note that there was a change in the nature of the response categories in 2018 compared to 2012 - with the removal of the 'neither/nor' option - we can be confident that the increase of opposition by 27 per cent cannot be explained simply by this change: the removal of this category is likely to have increased the proportion of those who disagreed with the statement, but we would also expect respondents who would ordinarily opt for 'neither/nor' to favour the status quo (term-limited) option. Potentially, this increase in opposition to term limits presents a social basis of support for constitutional change.

However, Russian citizens also remain divided on this issue, which presents the possibility that any future change could meet resistance.

\section{- TABLE $2-$}

In the remainder of this article, we analyse the nature of this support for and against term limits in Russia. As we will show, our survey research for 2012 indicates that supporters of term limits were significantly more likely to be supporters of authoritarian leadership. Is that still the case? Also, as we note above, earlier research indicated that concerns about term limits was a factor leading to support for protests that erupted. Would their abolition now also connect to protest support?

In the next section, we explore the hypotheses that will guide this analysis.

\section{Theoretical expectations about public support for term limits in Russia}

The comparative literature on presidential systems limits presents a number of normative arguments about the purported effects of term limits on both democratic and authoritarian 
political systems. These normative hopes ought to help shape expectations of the social constituents in their support. As far as we are aware, however, there have been few attempts to test these arguments at the level of individual citizens. Existing research has largely dealt with country-level polling data on attitudes towards term limits (Dulani, 2015). Nonetheless, the extant literature on the pros and cons of term limits, which has been discussed in the context of both democratic and authoritarian systems (Baturo, 2010; Baturo, 2014), is sufficiently wide-ranging to be a meaningful basis for the analysis of public opinion in Russia. In this section, we reference these arguments (five in total) and introduce the variables that we will use to test them.

Much of the extant literature expounds the view that term limits prevent tyranny, or are at the very least strongly associated with democratic government (Elkins et al. 2009; Ginsburg, Melton and Elkins, 2011; Baturo, 2014; Baturo and Elgie, forthcoming). This widely held view centres on the liberal idea that term limits provide checks that deter presidents from using the powers of their office to undermine democracy. This is illustrated by examples from both democratic and authoritarian systems. There is ample empirical evidence to support the contention that term limits are more likely to survive in democratic political systems (Baturo and Elgie, forthcoming). Consequently, international bodies which seek to promote democratic constitutions like the Venice Commission, place emphasis on the need for term limits in any new constitutional design (Venice Commission, 2018). Thus, first, we expect that those Russian citizens who support democratic norms will be more willing to support term limits. We test this hypothesis using the following question:

Tell us, please, what do you think about the idea that a democracy, in which multiple parties compete for power, is the best system for governing Russia. 
Likewise, we also expect that citizens who would be willing to countenance rule by an authoritarian leader would be less likely to back constitutional restrictions on presidential terms in office. We use the following question to test this related hypothesis:

It will be worthwhile to support a leader who could solve the main problems facing the Russian Federation today even if he overthrew democracy.

At the same time, scholars note that while term limits are a check on dictatorial behaviour, this can be at the expense of electoral accountability and choice. Term limits are criticised for weakening the connection between leaders and voters by removing the electoral accountability of second term presidents (Cheibub, 2007). More importantly, they also place restrictions on the ability of the majority of citizens to choose leaders to represent them for more than a constitutionally pre-determined number of terms (Baturo, 2014, p. 11). From a majoritarian viewpoint, term limits therefore deny citizens the right to re-elect incumbent presidents who they deem to be popular and competent. As Baturo (2014, p. 40) argues "while restrictions on re-election can prevent leaders from accumulating incumbency advantage at the polls, they can also deprive people of capable leaders."

This majoritarian argument is important in the Russian context. Research shows that support for Vladimir Putin derives in part from voters' satisfaction with his performance in office (Whitefield, 2009). Thus, second, we expect Russian citizens who support President Putin to be more likely to oppose term limits. We test this hypothesis using the question: In the election for president of the Russian Federation in March 2018 who did you vote for?

Another argument that features in the literature on term limits concerns the opportunities that they provide for competing political interests to access power. Given the advantages that incumbents enjoy, elections do not guarantee the transfer of power, and this 
is even less likely in electoral authoritarian systems such as Russia's (Corothers, 2002). Hence, term limits provide a way of lowering the barriers to entry through the regular rotation of political leaders (Baturo 2014, p. 3). This is thought to have positive benefits for citizens who are apathetic about politics. Greater competition and increased chances of political change is seen as a way of incentivising the politically marginalised to participate in the political process (Baturo 2014, p. 222). Thus, third, we expect Russian citizens who consider themselves to have low political efficacy to support term limits. We explore this hypothesis with the question:

There is no point in voting because the government can't make any difference

The literature on term limits also suggests that restrictions on the tenure of leaders provide a means of curbing the development of highly personalised, clientelistic relationships that are likely to infect the political system when the tenure of leaders is unchecked. As McKie (2017, p. 437) notes: "formal tenure limitations are designed to promote the rule of law over the rule of man"; they restrict the opportunity for presidential incumbents to enrich themselves and their supporters. Thus, fourth, we expect Russian citizens who are concerned about official corruption to be more likely to support term limits. We consider this hypothesis with the survey question:

How widespread do you think corruption such as bribe taking is amongst politicians in RF?

Furthermore, there is a more critical perspective on term limits, which posits the view that the regular rotation of leadership introduces unnecessary uncertainty into the political system. Such uncertainty is particularly problematic for those citizens whose personal welfare is dependent upon the government's ability to provide credible commitments, especially in the economic sphere. From this perspective, term limits reduce the time horizons of 
politicians and distort policy-making, which is likely to be resisted by those citizens who gain most from political continuity (Baturo, 2014; Baturo and Elgie, forthcoming). Thus, fifth, we hypothesise that Russian citizens who expect to gain economically from Putin's second term would be the most likely to oppose term limits. We test this hypothesis using the question And looking ahead over the next five years, do you think that your household's standard of living will fall a great deal from its current level, fall a little, stay about the same as it is now, rise a little, or rise a lot from its current level?

In addition to these five explanatory variables, we include a number of control variables, which are associated with support for term limits. They include age, education, political awareness and urban residence. These variables are significant predictors of support for term limits in studies of public opinion in Africa and Latin America (Dulani, 2015; Doyle, forthcoming). We also include a dummy variable for citizens employed by the state, which is relevant for our understanding of Russian politics, and for support for term limits elsewhere (Baturo, 2010). Research finds that this category of citizens is an important component of Vladimir Putin's political coalition (Chaisty and Whitefield, 2012; Rosenfeld, 2017), and we therefore assume it is likely to predict support for issues associated with any extension of Putin's tenure in office.

Finally, we explore the likely political costs of any attempt by Vladimir Putin to extend or abolish term limits. We do this by examining the extent to which support for term limits connects to the willingness of Russian citizens to protest against the authorities. The comparative literature asserts that term limits lower the likelihood of rebellion in electoral authoritarian systems (Elkins et al. 2009). By providing an institutional mechanism for the rotation of power, this scholarship contends that term limits reduce the danger of the removal 
of presidents by violent coups or rebellions. We consider this risk by analysing whether advocates of term limits are more likely to protest. We do this using the following question:

\section{How likely are you to take part in a peaceful protest in support of issues you care about?}

Detailed notes on this question and all the other questions included in the analysis are available in Appendix B.

These theoretical expectations were largely supported by our survey findings in 2012 (see Table 3). When all the explanations were considered simultaneously in ordinal logistic regression of the full sample, respondents who had low confidence in the efficacy of the political system and were concerned about elite-level corruption were significantly more likely to support term limits, while Putin's supporters were more likely to oppose them. ${ }^{3}$ These results also held for Putin's supporters, along with economic winners within the Putin camp who, as hypothesised, were more likely to oppose term limits. However, there was one notable exception in 2012: citizens who favoured an authoritarian leader capable of solving the countries problems. In contrast to our theoretical expectations, these citizens were significantly more likely to support term limits than those who opposed this idea. This counterintuitive finding about the relationship between normative orientations towards democratic leadership and term limits was also matched by weak evidence to suggest that the supporters of democracy in general were more likely to favour constraints on the president's ability to serve more than two terms. Amongst Putin's own supporters this factor had no effect, and in the full model its limited significance was removed when the 'anti-democratic leader' variable was excluded from the analysis.

\footnotetext{
${ }^{3}$ The dependent variable (support for term limits) is ordered from 'strongly disagree' to 'strongly agree', with respondents who were undecided ('neither/nor' or 'did not know') coded as the middle category. We follow the same coding rule when dealing with the undecided respondents for all the independent variables.
} 


\section{- TABLE 3 -}

We account for this surprising result in light of the characteristics of the nationalist supporters of the Bolotnaya protests, who were more likely to be anti-democratic in their perspectives. In our earlier work we found that respondents who held strong ethnonationalist attitudes (XXXXX) and supported nationalist parties like Vladimir Zhirinovsky's Liberal Democratic Party (LDPR) (XXXX), were significantly more likely to support term limits, even though their political leadership was often opposed. ${ }^{4}$ Putin's shift in an authoritarian nationalist direction following his re-election was plausibly linked at least in part to his need to rebuild support among this group of active and politically dangerous citizens.

In the next section, we consider to what extent these findings were replicated in the survey of attitudes towards term limits and political protest in 2018.

\section{Who supports term limits and might they protest at their removal?}

We start by addressing the question of who supports and opposes term limits in light of the theoretical and normative expectations just developed. We also bear in mind our findings from 2012. While many expectations were met about constituencies of support, at that time democrats were not more likely to be among them or to be supporters of protest against the return of Vladimir Putin. In fact, citizens who were more willing to overthrow democracy were the ones who were more likely to support term limits. Citizens with low political efficacy however were more supportive as were those who opposed corruption. Opposition

\footnotetext{
${ }^{4}$ Vladimir Zhirinovsky has consistently supported the removal of term limits (see (see Farizova 2007).
} 
to term limits came mainly from Putin supporters, not surprisingly, and from the economic winners within the Putin camp. So, while in the main theoretical expectations were met, on one main dimension - that democrats rather than authoritarians should support term limits they were not.

We have seen above that opposition to term limits has increased significantly since 2012. Has the basis of support and opposition also changed? And is the fact that 40 per cent plus remain supportive still politically significant? Who are the supporters, within the general population and even amongst Putin's own voters?

As with the analysis for the 2012 survey, we use ordinal logistic regression to address these questions (see Table 4). This analysis is appropriate for the ordered scale that measures support for term limits. We also include the same range of theoretically relevant predictors for democracy support, political efficacy, economic winners, opposition to corruption, and Putin supporters, along with a range of controls. Taken overall, the hypothesised factors are statistically significant apart from the predictor that estimates corruption perceptions. Interestingly, this variable declined from being the most significant predictor of support for term limits in the full model in 2012 to having no significance in the analysis of either the full sample or the sub-sample of Putin's voters in 2018. Given that mean attitudes on this question changed little between 2012 and 2018 (see Appendix B), the finding suggests that the effect of perceptions of corruption on attitudes towards the authorities are likely to be mediated by support for President Putin. In 2012, attitudes on the question of corruption were strongly associated with support for the electoral protests against Vladimir Putin's decision to return to the Kremlin (Chaisty and Whitefield 2015, p. 9).

- TABLE 4 - 
To interpret the substantive significance of these results, we generate marginal effects for the variables that achieve statistical significance, while holding all the other variables in the model at their means. The marginal effects for the full and reduced samples are presented in Figures 1 and 2. These charts illustrate the difference in probabilities between those respondents who held positive and negative attitudes on each predictor, when the question of whether respondents strongly agreed that presidents should not be allowed to serve more than two terms in total was regressed.

\section{FIGURE $1 \& 2$}

The results for both samples show similarities and some contrasts with 2012. Perhaps not surprisingly, Putin supporters were more likely to support term limits, although their marginal effect is slightly less than in 2012, when all the other variables were held at their means. In 2018, Putin supporters were around 7 per cent less likely to support term limits than those who supported other candidates. But, more striking is the strengthening of the effect among those who expected to benefit personally from the Russian economy under Putin's leadership. In line with our theoretical discussion, those who expect to be economically successful under Putin's presidency were much more likely to oppose term limits in 2018. In the 2012 survey, in contrast, this factor was significant for Putin's voters only, and it remained at a similar level of significance for Putin's voters in 2018, while being strongly significant for the full sample. Those who we describe as 'future winners' were over 20 per cent more likely to oppose term limits in 2018 . The strengthening of this factor may be indicative of the consequences of Russia's economic problems since the Ukrainian crisis of 2014. It suggests that those who expect their personal finances to deteriorate would be significantly more likely to support constitutional limits on the president's time in office 
As in the 2012 survey, those citizens who have a low sense of their political efficacy were much more likely to support term limits in 2018 . This was the only predictor across both survey waves that had consistently strong effects for both the full and the reduced samples. In 2018, those citizens who believed that there was no point in voting were over 20 per cent more likely to support term limits within the full sample and even among Putin's own supporters. Although the magnitude of this considerable effect was less than in 2012, it is a robust finding and fits with the broad expectations raised in the comparative literature discussed above.

Of the control variables, urban citizens in both 2018 and 2012 were much more likely to support term limits in the full and reduced samples, although their overall effect was small. But, in contrast to 2012, we found that those citizens who were interested in politics were more likely to support term limits. This effect was consistent across respondents in both samples. However, among Putin voters, more educated respondents were more likely to oppose term limits in 2018, as were state employees, which was consistent with our expectations.

Most interestingly, we note one important shift in the base of support for term limits that was not present in 2012 that brings Russian public opinion more fully in line with normative theories of who should support them. Namely, Russians who were more committed to democracy in principle were now much more likely to be supportive of term limits in both samples. In 2018, citizens who agreed or strongly agreed that democracy in which multiple parties compete for power was the best system for governing Russia, were 16 per cent more likely to support term limits in the full sample, and 15 per cent more likely to be supportive among Putin's voters. This finding was even more pronounced in the analysis of those citizens who were willing to support authoritarian leaders. Whereas in 2012, 
authoritarian supporters were 20 per cent more likely to support limits on presidential terms of office, in 2018 this had moved in the opposite direction: they were 10 per cent more likely to oppose any restrictions on the president's tenure. So, while term limits in 2012 were more likely to be supported by more authoritarian Russians who were at the time often strongly critical of the regime, Putin's swing towards nationalism on his resumption of office appears to have mitigated their hostility to limits on presidential terms at the mass level, ${ }^{5}$ but at the price of alienating many democrats. In contrast to the findings for 2012 , respondents in 2018 who held strong ethno-nationalist views and/or supported Zhirinovsky's nationalist LDPR party were neutral on the question of support for term limits. ${ }^{6}$

As we noted in the discussion of the political salience of term limits above, the issue of whether Putin was acting in the spirit of the constitutional law on how many times he could hold office was a catalyst for supporting protest activity against the regime in 2011-12. What then might be the relationship between stances on term limits and support for protest in 2018? Clearly, there are many obstacles to actual protest behaviour in any political context, including resources and collective action problems. In the Russian case, oppressive and coordinated action by the authorities to prevent it would likely feature strongly (Robertson, 2010). However, given the history of significant mobilisation prompted in part by views of term limits in the recent past, it is worth considering whether there is a base of support for protest around this issue.

\section{FIGURE 3}

\footnotetext{
${ }^{5}$ Attitudes amongst nationalist elites have not consistently followed mass attitudes. Putin has continued to face criticism from nationalist leaders, even after the annexation of Crimea in 2014 (see Kolst $\varnothing$ and Blakkisrud 2016).

${ }^{6}$ As per XXXXX, we identify respondents as ethno-nationalists if they held highly xenophobic attitudes on questions about Jewish people and Gypsies. In 2012, bivariate correlations between support for term limits and ethno-nationalist attitudes and support for LDPR were significant at the $p=>.001$ and $p=>.01$ levels. This analysis is available on request.
} 
We estimate protest potential by adding a variable to our model that estimates the willingness of citizens to take part in peaceful protest on support for presidential term limits. These data are taken from responses to the question: How likely are you to take part in a peaceful protest in support of issues you care about? The protest variable is strongly significant in the analysis of the full sample (p-value $>.000)$ and remains significant $(>.05)$ in the analysis of the reduced sample of Putin's own voters. ${ }^{7}$ This is illustrated by the predicted probabilities in Figure 3, which represent the difference between the sum of the probabilities of strongly supporting term limits between those who were somewhat or very likely to take part in peaceful protest, and those who were unlikely or very unlikely to protest. Holding all the other variables at their means, respondents in the full sample who expressed a willingness to take part in peaceful protests were almost 18 per cent more likely to agree strongly that the same person cannot be president of Russia for more than two terms in total than those unwilling to protest, while amongst Putin's supporters this probability fell to around 6 per cent. Thus, there remains a group of citizens willing to protest for whom term limits are a desirable feature of the Russian Constitution. Given the experience of 2011-12, this factor may influence any future decision to change the formal rules in this area.

\section{Conclusions}

What light does this analysis cast on the political dynamics of public opinion in the Russian political system?

We start by noting the oddity of Russian public opinion in 2012, from the perspective of normative theory on the advantages of term limits: citizens who were willing to countenance a leader willing and able to overthrow democracy were the most likely to

\footnotetext{
${ }^{7}$ These results are available on request.
} 
support limits on presidential tenure. We suppose that the two perspectives at that time were interrelated. If support for term limits in 2011-12 came significantly from the authoritarian nationalist camp, and this group was also a mainstay of mass protest activity against the regime, it may not be surprising that democrats were at that time neutral on the question. But the shift in policy of the regime towards greater nationalism since 2012 appears to have clarified the desirability of term limits among democrats and shifted opposition to them among anti-democrats. This shift may be a more broadly consequential one for the nature of support for Putin. Whereas since his assumption of power, he has often been more strongly supported by democrats who were judging him against the background of the Communist past (Whitefield, 2009), his presidency since 2012 may have shifted the judgements of Russian democrats to a backdrop of authoritarian nationalism. This would mark a major shift in the context of Russian public opinion in the post-Communist period and would suggest that constitutional views of term limits and protest appears to have become less anomalous from the perspective of the comparative literature and much more in line with general normative expectations.

Second, were abolition of term limits to be pursued, opposition and protest could be galvanised, as was the case in 2011-12. The nature of the opposition would be similar in many ways - urban, politically alienated but informed, and economically distressed. But in 2018, that group coincided with supporters of democracy who see term limits as a means to democratic goals. They are also a group that is significantly more likely to support protest, and their protest under the abolition of term limits scenario would take place in a context of considerable constitutional saliency. Protest mobilisation of course is highly contingent on many factors in authoritarian hybrid regimes, so its success is far from guaranteed. We must also question whether protest by alienated democrats is as politically dangerous in the 
Russian context as that by alienated authoritarian nationalists. However, a mobilised democratic body of citizens would mark a departure in politics under Putin.

Third, much will depend on Putin's own calculations. We note that he has never been a public supporter of the removal of term limits. As he remarked when asked about the possibility of him serving additional terms shortly after the 2018 presidential election: "Let's do the math here... Am I supposed to be in this post till I'm 100 years old? No!" [TASS, 2018]. Even he, therefore, may see the need for succession in the system and perhaps for retirement. Nonetheless, the risks to the system and to him personally of failed succession are potentially high enough to make it tempting to change the constitution. Opposition to term limits has grown which may raise the likelihood that Putin is motivated to abolish them. As we noted above, there are high stakes to standing by the constitution in this regard. Putin sits atop a clientelistic network that relies on his position for its security and stability. Contested elections to refill the top spot are politically dangerous and destabilising. While in 2008 Putin felt secure enough to step down as president to allow Dmitry Medvedev to occupy the office while be became Prime Minister, there is no guarantee that such a strategy would be a success again, for Putin personally or for the clientelistic system.

Finally, however, we note that the growth in opposition to term limits was driven largely by two factors: Putin's popularity and the strong support of economic winners. Abolishing term limits when these factors remain in place may reduce the risks. Even so, support for them remains large. And we note that Putin's popularity has fallen since the time at which the survey was undertaken and therefore may be a less reliable base of support; and the gains of economic winners may not be guaranteed in future. The temptations of abolishing term limits appear much less evident when they are popular and when the putative 
beneficiary of their end could find themselves facing a significant electoral challenge in which a coalition of Russians may be mobilised. 


\section{References}

Baturo, A. (2010). 'The Stakes of Losing Office, Term Limits and Democracy', British Journal of Political Science, 40:3,_pp. 635-662.

Baturo, A. (2014). Democracy, Dictatorship and Term Limits (Ann Arbor: The University of Michigan Press).

Baturo, A. and R. Elgie (eds.) (forthcoming). The Politics of Presidential Term Limits (Oxford: Oxford University Press).

Carothers, T. (2002). 'The End of the Transition Paradigm', Journal of Democracy 13:1, pp. 5-21.

Chaisty, P. (forthcoming). 'The Uses and Abuses of Presidential Term Limits in Russian Politics'. In A. Baturo and R. Elgie (eds.) The Politics of Presidential Term Limits (Oxford: Oxford University Press).

Chaisty, P. and S. Whitefield (2012), 'The Effects of the Global Financial Crisis on Russian Political Attitudes', Post-Soviet Affairs 28:2, pp. 187-20

Chaisty, P. and S. Whitefield (2013). 'Forward to democracy or back to authoritarianism? The attitudinal bases of mass support for the Russian election protests of 2011-12', PostSoviet Affairs, 29:5, pp. 387-403.

Chaisty, P. and S. Whitefield (2017). 'Institutional Preferences in a Time of Crisis: Mass Attitudes towards Regional Decentralisation in War-Torn Ukraine', Political Studies, 65(4): 824-843.

Cheibub, J. (2007). Presidentialism, Parliamentarism, and Democracy. (New York: Cambridge University Press).

Coalson, R. (2007). 'Russia: The Political Advantages of Instability'. RFE/RL Russia Report, 11 April. Available at https://www.rferl.org/a/1075817.html (accessed 19 July 2017).

Dobrynina, E. (2007). 'Regiony troitsu poka ne lyubyat'. Rossiiskaya gazeta, 20 April.

Doyle, D. (forthcoming). 'Term Limits in Bolivia'. In A. Baturo and R. Elgie (eds.) The Politics of Presidential Term Limits (Oxford: Oxford University Press).

Dulani, B. (2015), 'African Publics Strongly Support Term Limits, Resist Leaders' Efforts to Extend their Tenure', Afrobarometer Dispatch No. 30, 25 May, pp. 1-12.

Elkins, Z., T. Ginsburg and James Melton (2009). The Endurance of National Constitutions (Cambridge: Cambridge University Press).

Farizova, Syuzanna 2007. 'Gosduma gotova uvelichit' srok polnomochii prezidenta.' Kommersant’ daily, 5 June. 
Ginsburg, T, J. Melton and Z. Elkins (2011). 'On the Evasion of Executive Term Limit', William and Mary Law Review, 52: 6, pp. 1807-1872.

Golobachev, V. (2004). 'Opros. Maksimal'no berezhno - k konstitutsii'. Trud, 7 February

Gordeev, I. and M. V'iugin (2007). 'Ostavaites' nad nam'. Vremia novostei, 31 October.

Hale, H. (2015). Patronal Politics: Eurasian Regime Dynamics in Comparative Perspective (New York: Cambridge University Press).

Kolst $\varnothing$, P. and H. Blakkisrud (eds.) (2016), The New Russian Nationalism: Imperialism, Ethnicity and Authoritarianism 2000-2015 (Edinburgh: Edinburgh University Press).

Konstitutsionnoye soveshchanie (2005). Stenogrammy. Materialy. Dokumenty: 29 aprelya-10 noyabrya, Tom 6, 11 iyunya 1993 (Moskva: Izdatel'stvo Yuridiicheskaya literatura).

Kidenis, A. (2007). 'Putin Forever', Russkii kur'er, 8 October.

Mckie, K. (2017). 'The Politics of Institutional Choice across Sub-Saharan Africa:

Presidential Term Limits', Studies in Comparative International Development, 52:1, pp. 436456.

RFE/RL's Kyrgyz Service (2018). 'Discord Deepens As Kyrgyz Ex-President Atambaev Slams Successor Over Arrests', 20 November. Available at https://www.rferl.org/a/discorddeepens-as-kyrgyz-ex-president-atambaev-slams-successor-over-arrests/29610751.html (accessed 4 January 2019).

Robertson, G. (2010). The Politics of Protest in Hybrid Regimes : Managing Dissent in PostCommunist Russia (Cambridge: Cambridge University Press).

Rodin, I. (2012), 'Poslednii otchet prem'era', Nezavisimaia gazeta, 12 April.

Rosenfeld, B. (2017). Reevaluating the Middle-Class Protest Paradigm: A Case-Control Study of Democratic Protest Coalitions in Russia. American Political Science Review, 111:4, pp. 637-652.

TASS (2018). 'Putin vows to abide by two-term limit on consecutive presidential tenures', 25 May 2018. Available at http://tass.com/politics/1006561 (accessed 17 September 2018).

Venice Commission (2018). Report on Term Limits. Available at https://www.venice.coe.int/webforms/documents/default.aspx?pdffile=CDL-AD(2018)010-e (accessed 6 January 2018).

Whitefield, S. (2009). 'Russian Citizens and Russian Democracy: Perceptions of State Governance and Democratic Practice, 1993-2007'. Post-Soviet Affairs, 25: 2, pp. 1-25.

Zhukov, M. (1998). 'El'tsin eshche mozhet stat' prezidentom'. Kommersant' daily, 6 November. 
Table 1: "The President of Russia should not hold this office for more than two terms in total" (March 2012). The percentage of respondents in favour and against.

\begin{tabular}{|l|r|r|}
\hline & $\mathrm{N}$ & $\%$ \\
\hline Strongly agree & 291 & 24.1 \\
\hline Agree & 337 & 27.9 \\
\hline Neither agree nor disagree & 225 & 18.7 \\
\hline Disagree & 177 & 14.7 \\
\hline Strongly disagree & 69 & 5.7 \\
\hline Don't know & 107 & 8.9 \\
\hline $\begin{array}{l}\text { Number of respondents in the } \\
\text { survey }\end{array}$ & 1206 & 100 \\
\hline
\end{tabular}

Table 2: "'How much do you agree or disagree that the same person cannot be president of Russia for more than two terms in total?" (April/May 2018). The percentage of respondents in favour and against.

\begin{tabular}{|l|r|r|r|}
\hline & $\mathrm{N}$ & $\%$ & $\begin{array}{r}\text { Change from } \\
2012(\%)\end{array}$ \\
\hline Strongly agree & 275 & 17.3 & -6.8 \\
\hline Agree & 407 & 25.6 & -2.3 \\
\hline Disagree & 443 & 27.9 & 13.2 \\
\hline Strongly disagree & 312 & 19.6 & 13.9 \\
\hline Don't know & 153 & 9.6 & \\
\hline $\begin{array}{l}\text { Number of respondents in the } \\
\text { survey }\end{array}$ & 1590 & 100 & \\
\hline
\end{tabular}

Note: The 'neither/nor' category was not available in the 2018 questionnaire. This reduced the number of undecided respondents in that survey wave, but it is unlikely to have caused the significant increase in the proportion of respondents opposed to term limits. 
Table 3: Ordinal logistic regression of the factors predicting support for presidential term limits in 2012

\begin{tabular}{|l|r|r|}
\hline & Full Model & Putin's Voters \\
\hline Democracy best system & $0.12^{*}$ & 0.14 \\
\hline Antidemocratic leader & $0.20^{* * *}$ & $0.14^{*}$ \\
\hline Putin voter & $-0.86^{* * *}$ & NA \\
\hline No point voting & $0.27^{* * *}$ & $0.51^{* * *}$ \\
\hline Politicians corrupt & $0.47^{* *}$ & $0.51^{* * *}$ \\
\hline Future winners & -0.10 & $-0.27^{* *}$ \\
\hline Age & 0.00 & -0.00 \\
\hline Education & 0.03 & 0.08 \\
\hline Interested in politics & -0.04 & $-0.16^{*}$ \\
\hline State employee & 0.06 & -0.29 \\
\hline Urban resident & $0.40 * *$ & 0.33 \\
\hline & & 0.08 \\
\hline Pseudo R2 & 0.07 & 462 \\
\hline Number & 1142 & \\
\hline
\end{tabular}

Table 4: Ordinal logistic regression of the factors predicting support for presidential term limits in 2018

\begin{tabular}{|l|r|r|}
\hline & Full Sample & Putin's Voters \\
\hline Democracy best system & $0.22^{* * *}$ & $0.30^{* * *}$ \\
\hline Antidemocratic leader & $-0.12^{* *}$ & -0.08 \\
\hline Putin voter & $-0.52^{* * *}$ & NA \\
\hline No point voting & $0.28^{* * *}$ & $0.35 * * *$ \\
\hline Politicians corrupt & 0.05 & -0.05 \\
\hline Future winners & $-0.29 * * *$ & $-0.34 * * *$ \\
\hline Age & 0.00 & 0.00 \\
\hline Education & -0.01 & $-0.14 *$ \\
\hline Interested in politics & $0.18^{* * *}$ & $0.14 * *$ \\
\hline State employee & -0.19 & $-0.41^{* *}$ \\
\hline Urban resident & $0.29 * *$ & $0.33 *$ \\
\hline & & 0.03 \\
\hline Pseudo R2 & 0.04 & 848 \\
\hline Number & 1585 & \\
\hline
\end{tabular}


Figure 1: Net probability of supporting term limits for the statistically significant predictors

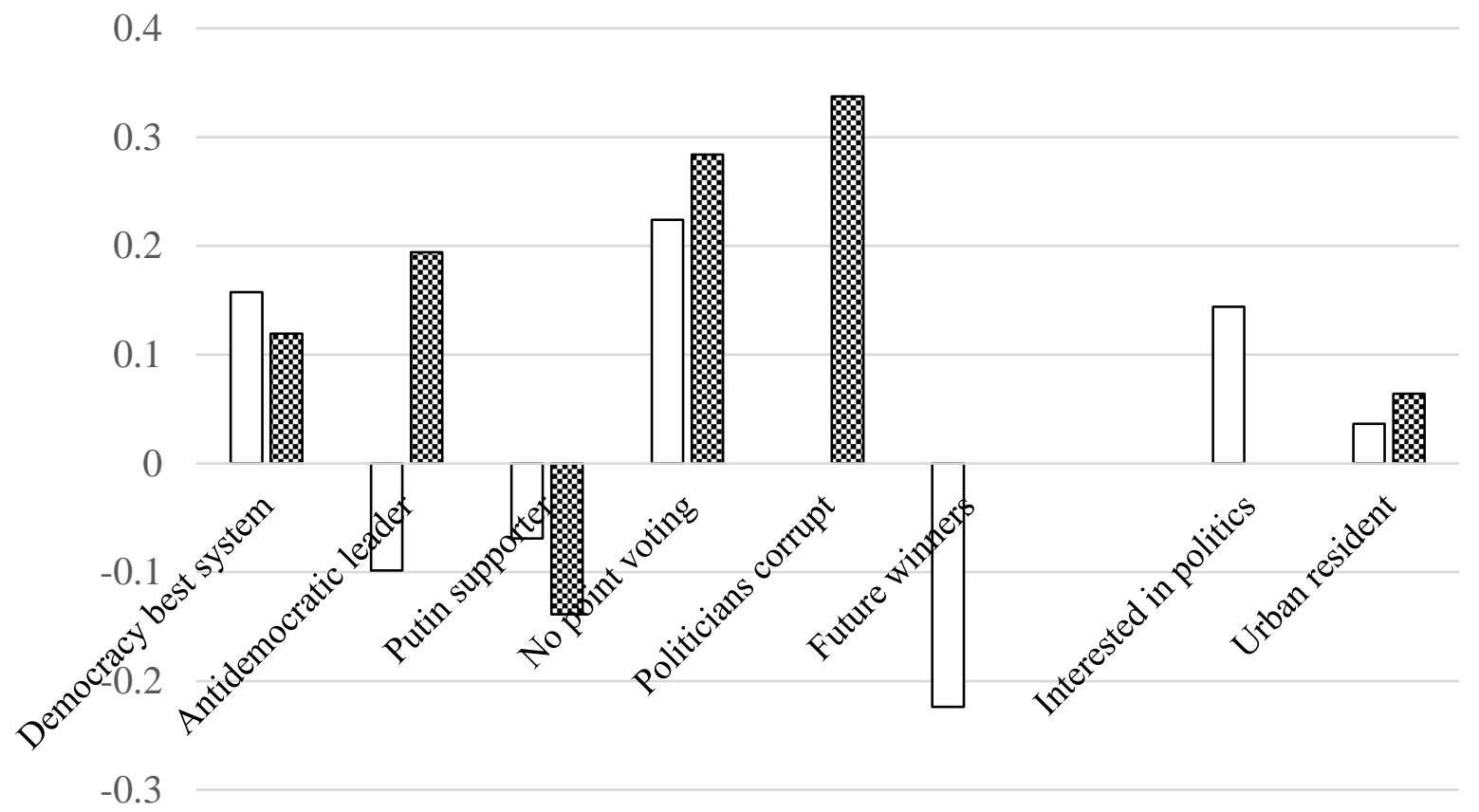

Figure 2: Net probability of supporting term limits for the statistically significant predictors - Putin supporters only

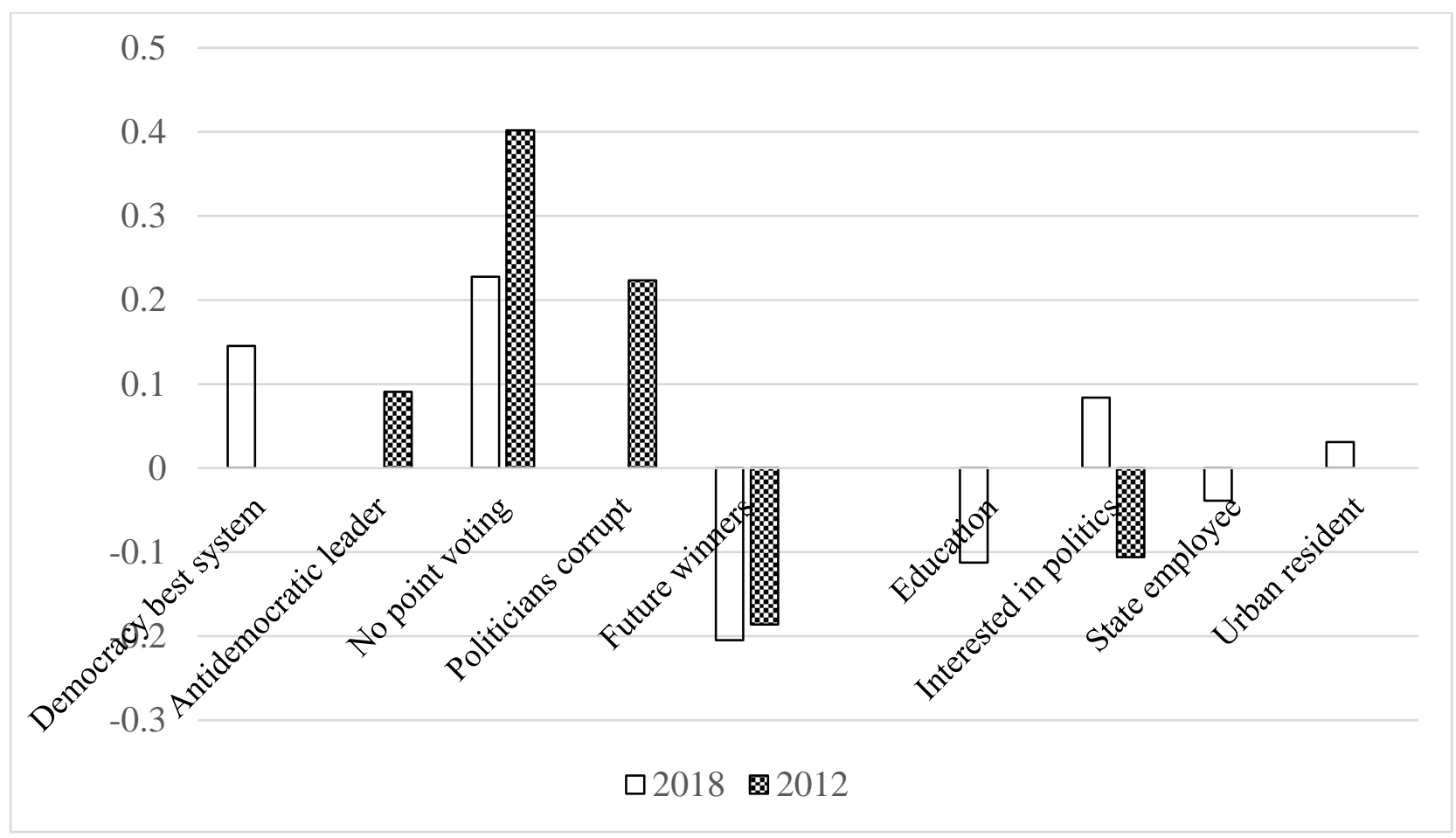


Figure 3: Willingness to engage in peaceful protest as a predictor of support for term limits (full sample and Putin's voters)

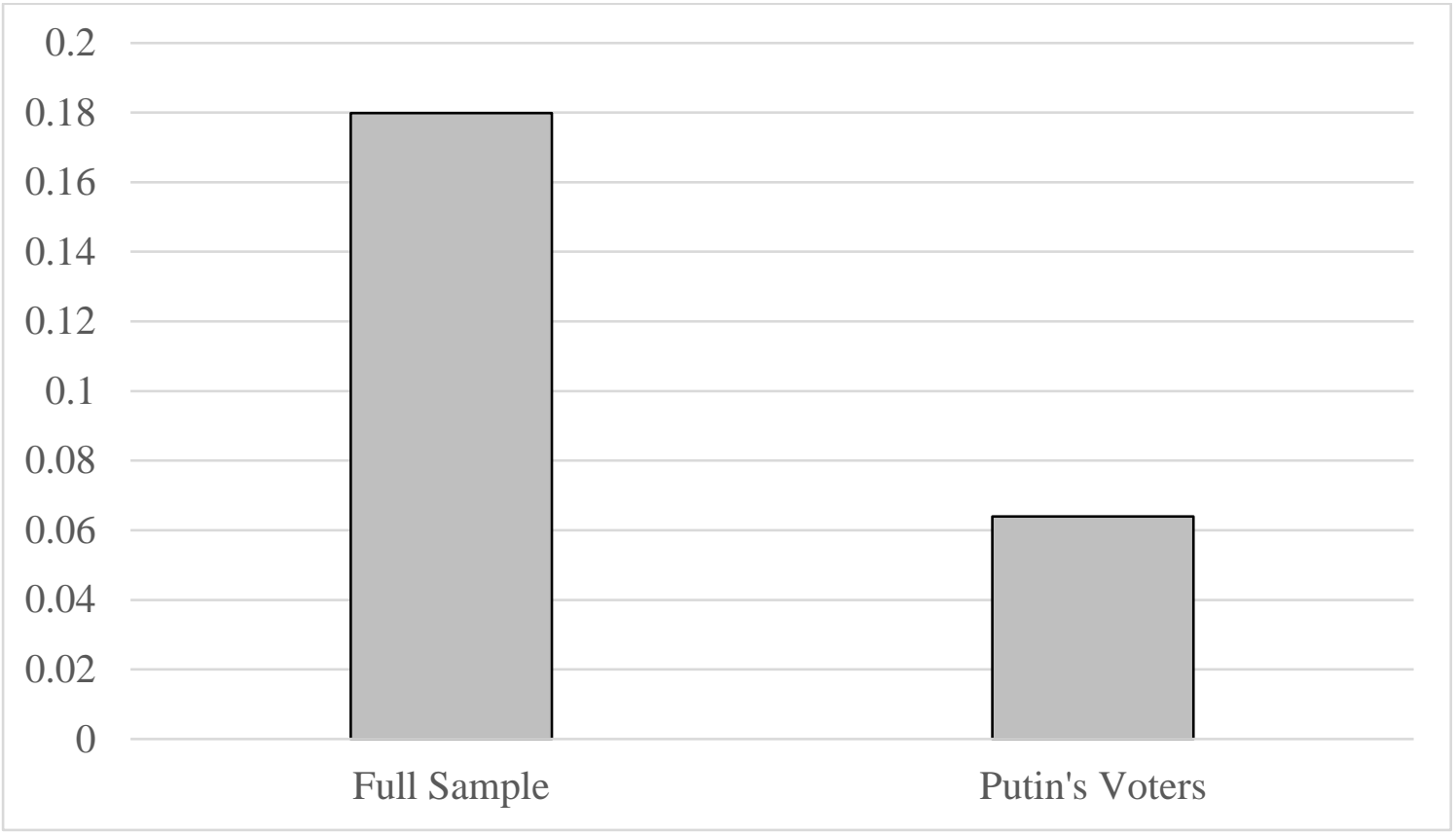


Appendix A. The 2012 and 2018 surveys ${ }^{8}$

\begin{tabular}{|c|c|c|c|}
\hline $\begin{array}{l}\text { March } \\
2012\end{array}$ & $\begin{array}{l}\text { Representation: national. } \\
\text { Sampling frame: Census } \\
\text { 2002, } 2010 \\
\text { Adult population (18+) }\end{array}$ & $\begin{array}{l}\text { Stratification Method } \\
\text { Stage 1: The territory of the } \\
\text { Russian Federation was divided } \\
\text { into } 7 \text { regions (Territorial- } \\
\text { Administrative Units TAUs) as } \\
\text { used in the official statistics. } \\
\text { Each TAU was represented in } \\
\text { the sample proportionally to its } \\
\text { population size. } \\
\text { Stage } 2: \text { The total number of } \\
\text { interviews in each survey } \\
\text { region was allocated to } 6 \text { strata } \\
\text { in proportion to the population } \\
\text { of each stratum. The strata were } \\
\text { defined on the basis of } \\
\text { settlement size. } \\
\text { Respondent Selection } \\
\text { Stage 1: The selection of } \\
\text { households (random route } \\
\text { method with a pre-determined } \\
\text { starting point). } \\
\text { Stage } 2: \text { The selection of } \\
\text { respondent (the most recent } \\
\text { birthday method. Only one } \\
\text { respondent per household was } \\
\text { interviewed). }\end{array}$ & $\begin{array}{l}\text { Response Rate: .51 } \\
\text { Respondent non- } \\
\text { contact: } 1180 . \text { Of } \\
\text { which refusals: } 440 \\
\text { Achieved: } 1206\end{array}$ \\
\hline $\begin{array}{l}\text { April/May } \\
2018\end{array}$ & $\begin{array}{l}\text { Representation: national. } \\
\text { Sampling frame: Census } \\
2010 \text { and periodic } \\
\text { publications by the State }\end{array}$ & $\begin{array}{l}\text { Stratification Method } \\
\text { Stage 1: The territory of the } \\
\text { Russian Federation is divided } \\
\text { into } 8 \text { FO as used in the official }\end{array}$ & $\begin{array}{l}\text { Response Rate: } .49 \\
\text { Respondent non- } \\
\text { contact: } 1631 . \text { Of } \\
\text { which refusals: } 503\end{array}$ \\
\hline
\end{tabular}

${ }^{8}$ Conducted by R-Research. 


\begin{tabular}{|c|c|c|}
\hline $\begin{array}{l}\text { Statistical Committee } \\
\text { (Goskomstat) as of } 1 \\
\text { January } 2017 \\
\text { Adult population (18+) }\end{array}$ & $\begin{array}{l}\text { statistics of } 1 \text { January } 2017 . \\
\text { Moscow and St. Petersburg are } \\
\text { considered as separate strata for } \\
\text { sampling purposes. Crimea and } \\
\text { Sebastopol are booster strata. } \\
\text { Initially, each region is } \\
\text { represented in the sample in } \\
\text { proportion to its population } \\
\text { size. } \\
\text { Stage 2: } 25 \text { primary sampling } \\
\text { units (PSUs - federal subjects) } \\
\text { selected out of } 85 \text { and } \\
\text { distributed across FOs } \\
\text { proportionally to their } \\
\text { population. Moscow and St. } \\
\text { Petersburg are regarded as } \\
\text { separate stratum, and Crimea } \\
\text { and Sebastopol were included } \\
\text { in the sample as boosters. } \\
\text { Within PSUs urban settlements } \\
\text { and rural districts were selected } \\
\text { using a probability proportional } \\
\text { to size (PPS) method of } \\
\text { selection. } \\
\text { Respondent Selection } \\
\text { Stage 1: The selection of } \\
\text { households (random route } \\
\text { method with a pre-determined } \\
\text { starting point). } \\
\text { Stage } 2: \text { The selection of } \\
\text { respondent (the most recent }\end{array}$ & Achieved: 1590 \\
\hline
\end{tabular}

\footnotetext{
${ }^{9}$ The comparison with 2012 was not affected by the inclusion of Crimea in the 2018 sample. The exclusion of Crimean respondents from the analysis for 2018 did not significantly alter the statistical results. This analysis is available on request.
} 


\begin{tabular}{|l|l|l|l|}
\hline & $\begin{array}{l}\text { birthday method. Only one } \\
\text { respondent per household was } \\
\text { interviewed). }\end{array}$ & \\
\hline
\end{tabular}

Appendix B: Variables in the analysis: 2012 and 2018 surveys

\begin{tabular}{|c|c|c|c|c|c|}
\hline Variable & $\begin{array}{l}\text { Mean } \\
2012 \\
(2018)\end{array}$ & $\begin{array}{l}\text { Median } \\
2012 \\
(2018)\end{array}$ & $\begin{array}{l}\operatorname{Max} \\
2012 \\
(2018)\end{array}$ & $\begin{array}{l}\text { Min } \\
2012 \\
(2018)\end{array}$ & $\begin{array}{l}\text { SD } \\
2012 \\
(2018)\end{array}$ \\
\hline $\begin{array}{l}\text { Democracy best system } \\
1=\text { Strong opponent } 2=\text { Opponent } 3=\text { Neither } \\
\text { opponent nor supporter } 4=\text { Supporter } \\
5=\text { Strong supporter }\end{array}$ & $\begin{array}{c}3.54 \\
(3.75)\end{array}$ & $\begin{array}{c}4 \\
(4)\end{array}$ & $\begin{array}{c}5 \\
(5)\end{array}$ & $\begin{array}{c}1 \\
(1)\end{array}$ & $\begin{array}{l}1.068 \\
(.959)\end{array}$ \\
\hline $\begin{array}{l}\text { Antidemocratic leader } \\
1=\text { Strongly disagree } 2=\text { Disagree } 3=\text { Neither } \\
\text { opponent nor supporter } 4=\text { Agree } 5=\text { Strongly } \\
\text { agree }\end{array}$ & $\begin{array}{c}3.37 \\
(3.36)\end{array}$ & $\begin{array}{c}3 \\
(3)\end{array}$ & $\begin{array}{c}5 \\
5 \\
(5)\end{array}$ & $\begin{array}{c}1 \\
(1)\end{array}$ & $\begin{array}{c}1.204 \\
(1.023)\end{array}$ \\
\hline $\begin{array}{l}\text { Putin voter } \\
0=\text { No } 1=\text { Putin voter }\end{array}$ & $\begin{array}{l}.41 \\
(.53)\end{array}$ & $\begin{array}{c}0 \\
(1)\end{array}$ & $\begin{array}{c}1 \\
(1)\end{array}$ & $\begin{array}{c}0 \\
(0)\end{array}$ & $\begin{array}{l}.492 \\
(.499)\end{array}$ \\
\hline $\begin{array}{l}\text { No point voting } \\
1=\text { Strongly disagree } 2=\text { Disagree } 3=\text { Neither } \\
\text { opponent nor supporter } 4=\text { Agree } 5=\text { Strongly } \\
\text { agree }\end{array}$ & $\begin{array}{l}2.80 \\
(2.90)\end{array}$ & $\begin{array}{c}3 \\
(3)\end{array}$ & $\begin{array}{l}5 \\
5\end{array}$ & $\begin{array}{c}1 \\
(1)\end{array}$ & $\begin{array}{c}1.195 \\
(1.032)\end{array}$ \\
\hline $\begin{array}{l}\text { Politicians corrupt } \\
1=\text { It hardly happens at all 2= Not very } \\
\text { widespread 3= Quite widespread 4=Very } \\
\text { widespread }\end{array}$ & $\begin{array}{c}4.20 \\
(4.14)\end{array}$ & $\begin{array}{c}4 \\
(4)\end{array}$ & $\begin{array}{c}5 \\
(5)\end{array}$ & $\begin{array}{c}1 \\
(1)\end{array}$ & $\begin{array}{l}1.039 \\
(.969)\end{array}$ \\
\hline $\begin{array}{l}\text { Future winners } \\
\text { (standard of living will) } 1=\text { Fall a lot } 2=\text { Fall a } \\
\text { little } 3=\text { Be the same } 4=\text { Rise a little } 5=\text { Rise a } \\
\text { lot }\end{array}$ & $\begin{array}{l}3.10 \\
(2.87)\end{array}$ & $\begin{array}{c}3 \\
(3)\end{array}$ & $\begin{array}{c}5 \\
(5)\end{array}$ & $\begin{array}{c}1 \\
(1)\end{array}$ & $\begin{array}{l}9915 \\
(.880)\end{array}$ \\
\hline $\begin{array}{l}\text { Age } \\
\text { Open ended (18+) }\end{array}$ & $\begin{array}{c}43.83 \\
(46.10)\end{array}$ & $\begin{array}{c}43.50 \\
(45)\end{array}$ & $\begin{array}{c}87 \\
(87)\end{array}$ & $\begin{array}{c}18 \\
(18)\end{array}$ & $\begin{array}{c}16.738 \\
(16.400)\end{array}$ \\
\hline $\begin{array}{l}\text { Education } \\
\text { 1= No qualification } 2=\text { Unfinished secondary } \\
\text { level } 3=\text { Secondary level } 4=\text { Special } \\
\text { secondary level } 5=\text { Higher education } \\
6=\text { Degree }\end{array}$ & $\begin{array}{c}3.91 \\
(3.84)\end{array}$ & $\begin{array}{c}4 \\
(4)\end{array}$ & $\begin{array}{c}6 \\
(6)\end{array}$ & $\begin{array}{c}1 \\
(1)\end{array}$ & $\begin{array}{c}.921 \\
(1.069)\end{array}$ \\
\hline $\begin{array}{l}\text { Interested in politics } \\
1=\text { Not at all } 2=\mathrm{A} \text { little } 3=\text { Somewhat } 4=\text { Very }\end{array}$ & $\begin{array}{c}3.04 \\
(2.90)\end{array}$ & $\begin{array}{c}4 \\
(2.50)\end{array}$ & $\begin{array}{l}5 \\
(5)\end{array}$ & $\begin{array}{c}1 \\
(1)\end{array}$ & $\begin{array}{c}1.312 \\
(1.331)\end{array}$ \\
\hline $\begin{array}{l}\text { State employee } \\
0=\text { No } 1=\mathrm{Yes}\end{array}$ & $\begin{array}{l}.043 \\
(.34)\end{array}$ & $\begin{array}{c}0 \\
(0)\end{array}$ & $\begin{array}{c}1 \\
(1)\end{array}$ & $\begin{array}{c}0 \\
0\end{array}$ & $\begin{array}{l}.495 \\
(.475)\end{array}$ \\
\hline $\begin{array}{l}\text { Urban resident } \\
0=\text { No } 1=\text { Yes }\end{array}$ & $\begin{array}{l}.74 \\
(.75)\end{array}$ & $\begin{array}{c}1 \\
(1)\end{array}$ & $\begin{array}{c}1 \\
(1)\end{array}$ & $\begin{array}{c}0 \\
(0)\end{array}$ & $\begin{array}{l}.436 \\
(.436)\end{array}$ \\
\hline
\end{tabular}


